\title{
The mechanism of the acute antihypertensive effects of captopril in patients on hemodialysis
}

\author{
Minoru Yamakado, M. D., Toshihiko Ishimitsu, M. D. and Hitoshi Tagawa, M. D. \\ Division of Nephrology and Hypertension, Department of Internal Medicine, \\ Mitsui Memorial Hospital
}

(昭和 61 年 12 月 9 日受付)

key words : captopril, hemodialysis, renin-angiotensin-aldosterone, bradykinin, angiotensin converting enzyme 〈Abstract〉

To examine the mechanisms of the acute antihypertensive effect of captopril in 10 patients with chronic renal failure on maintenance hemodialysis (HD), we measured the mean blood pressure (MBP), plasma renin activity (PRA), plasma aldosterone concentration (PAC), plasma bradykinin concentration (PBK), serum converting enzyme activity (ACE) and blood concentration of captopril (BSQ) before and 1, 2, 4 and 6 hours after the oral administration of captopril. After the administration of captopril, the MBP was significantly reduced from 117士 5 to $102 \pm 5 \mathrm{mmHg}(\mathrm{p}<0.01)$ and the ACE was significantly suppressed from $12.8 \pm 1.3$ to $7.8 \pm 1.6 \mathrm{mU} / \mathrm{ml}(\mathrm{p}<$ $0.01)$. The PRA significantly increased from $1.7 \pm 0.8$ to $3.1 \pm 1.6 \mathrm{ng} / \mathrm{m} / / \mathrm{h}(p<0.05)$ and the PBK significantly increased from $29 \pm 5$ to $42 \pm 6 \mathrm{pg} / \mathrm{ml}(\mathrm{p}<0.01)$. The PAC significantly decreased from $154 \pm 44$ to $134 \pm 39$ $\mathrm{pg} / \mathrm{m} l(\mathrm{p}<0.01)$. Changes in MBP were significantly correlated with basal PRA $(r=-0.75, p<0.01)$, basal PAC $(r=-0.72, p<0.01)$ and changes in PRA $(r=-0.72, p<0.01)$, but not with PBK or ACE. The maximum BSQ was obtained 1 hour after the administration and it showed a delay in its disappearance. There was no correlation between changes in MBP and BSQ.

These results suggest that the acute antihypertensive effect of captopril is mainly due to the inhibition of the renin-angiotensin-aldosterone system rather than the kinin system, even in patients on HD.

\section{血液透析患者における captopril の急性降圧機序}

\section{山門実 石光 俊彦 多川 斉}

三井記念病院内科・腎センター

カプトプリルの血液透析 (HD) 患者における急性降圧機序を検討する目的で, 10 例の HD 患者にカプトプリル 25 $\mathrm{ng}$ を経口投与し, 平均血圧 (MBP), 血漿レニン活性 (PRA), 血漿アルドステロン濃度 (PAC), 血漿ブラティキニ ン濃度 (PBK), 血清アンジオテンシン変換酵素 (ACE) 活性と, カプトプリル血中濃度 (BSQ) を, カプトプリル投 与前, 投与後 $1,2,4,6$ 時間と経時的に測定した。

カプトプリル投与後, MBP は $117 \pm 6$ より $102 \pm 5 \mathrm{mmHg}$ へと有意に下降し（ $\mathrm{p}<0.01), \mathrm{ACE}$ 活性は $12.8 \pm 1.3$ より $7.8 \pm 1.6 \mathrm{mU} / \mathrm{m} l$ へと有意に抑制された $(p<0.01)$. PRA は $1.7 \pm 0.8$ より $3.1 \pm 1.6 \mathrm{ng} / \mathrm{m} l / \mathrm{h}$ 一と有意に上

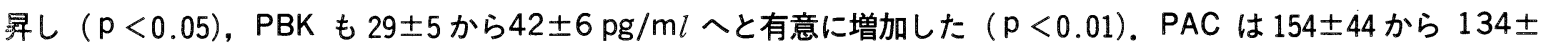
$39 \mathrm{pg} / \mathrm{m} l$ へと有意に減少した $(\mathrm{P}<0.01)$. カプトプリルによる血圧の变化量は, PRA 基礎値, PAC 基礎值产して PRA 変化量との間に有意の相関を認めたが(それ炎れ $r=-0.75, p<0.01 ; r=-0.72, p<0.01 ; r=-0.72$, $\mathrm{p}<0.01)$, PBK あるいは ACE 活性との間には相関を認めなかった. BSQ はカプトプリル投与 1 時間後に最高値を 示し, その減衰は遷延した。 また, 血圧の変化量と BSQ との間には相関を認めなかった。

以上の成績は, HD 患者においても, カプトプリルの急性降圧機序はレニン・アンジオテンシン・アルドステロン 系の抑制作用が主であり，キニン系に対する作用は少ないことを示すものと思われる. 


\section{Introduction}

Adequate blood pressure control is essential for patients on maintenance hemodialysis to avoid cardiovascular complications. The effectiveness of captopril, an orally active converting enzyme inhibitor, has now been established by many investigators in treating many types of hypertension ${ }^{1)}$ including hypertension associated with renal failure ${ }^{2,3)}$. The antihypertensive effect of captopril may be due to both elimination of angiotensin II and accumulation of bradykinin $^{5)}$. However, the role of the kinin system in the antihypertensive mechanism of captopril is still controversial $^{6)}$. Also, the pharmacokinetics of captopril are highly influenced by the excretory function of the kidney ${ }^{7)}$. So, in this study, we attempted to determine the role of the kinin system in the antihypertensive mechanism of captopril in patients on hemodialysis, and we investigated further the possible relationship between plasma-unchanged captopril bioavailability and its clinical effects.

\section{Patients and Methods}

We studied ten patients on regular hemodialysis : 4 males, 6 females, mean age 53 with a range of 32-62. All patients had their own kidneys and they were free of edema and judged to be at their dry weight. Also, no patient was taking antihypertensive medications. The study was performed on the next morning after a routine hemodialysis. Blood pressure, pulse rate, plasma renin activity (PRA), plasma aldosterone concentration (PAC), plasma bradykinin concentration $(\mathrm{PBK})$, serum angiotensin converting enzyme activity (ACE), and blood concentration of captopril (BSQ) were measured before and 1, 2, 4 and 6 hours after the oral administration of $25 \mathrm{mg}$ of captopril. Blood pressure and pulse rate were continuously measured by an automatic sphygmomanometer. PRA, $\mathrm{PAC}$ and PBK were measured by radioimmunoassay. ACE was measured by colorimetry and BSQ was measured as the free form of unchanged captopril by high pressure liquid chromatography ${ }^{8}$.

Results are expressed as mean \pm SEM. All data were analyzed by Student's t test and linear regression lines were obtained by the least squares method. A p-value less than 0.05 was considered statistically significant.

\section{Results}

Captopril significantly reduced systolic and dias-

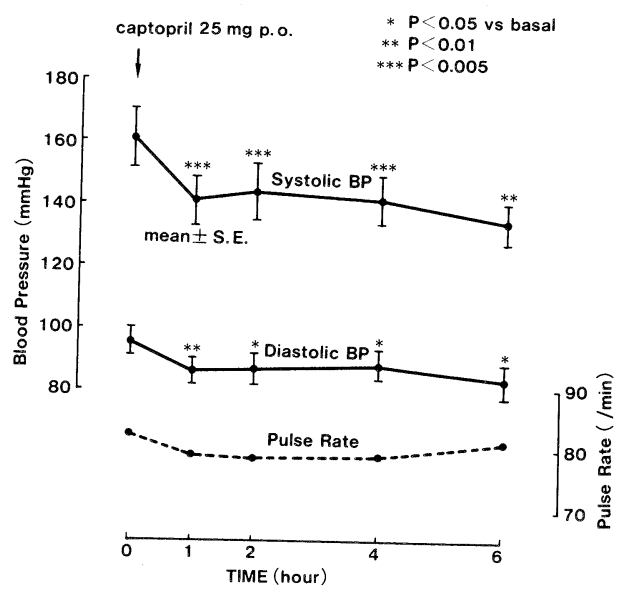

Fig. 1 Effects of captopril on systolic and diastolic blood pressure and pulse rate in patients on hemodialysis

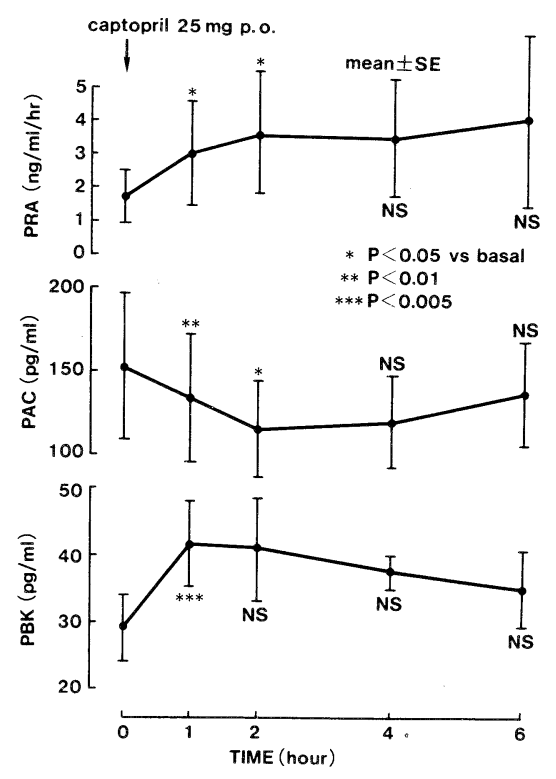

Fig. 2 Effects of captopril on plasma renin activity (PRA), plasma aldosterone concentration (PAC) and plasma bradykinin concentration (PBK) in patients on hemodialysis

tolic blood pressure 1 hour after the administration of captopril and this effect continued for 6 hours. On the other hand, the pulse rate remained unchanged throughout the experiment (Fig. 1).

The effects of captopril on PRA, PAC and PBK are shown in Fig. 2. PRA was significantly increased 1 hour after captopril administration and continued to 


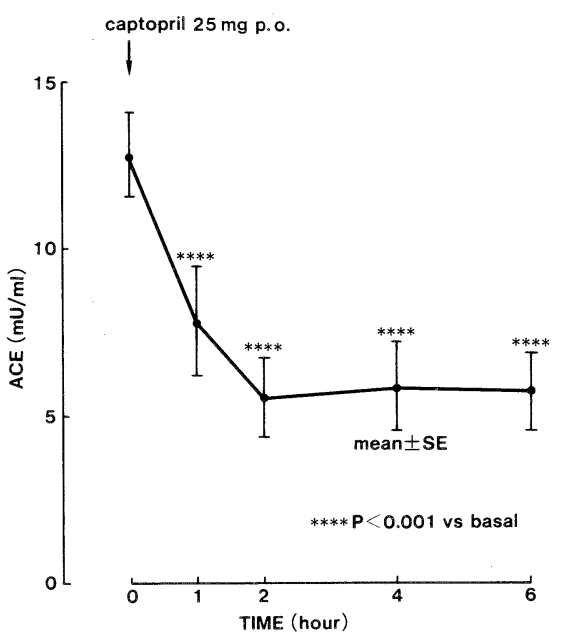

Fig. 3 Effects of captopril on serum angiotensin converting enzyme activity (ACE) in patients on hemodialysis

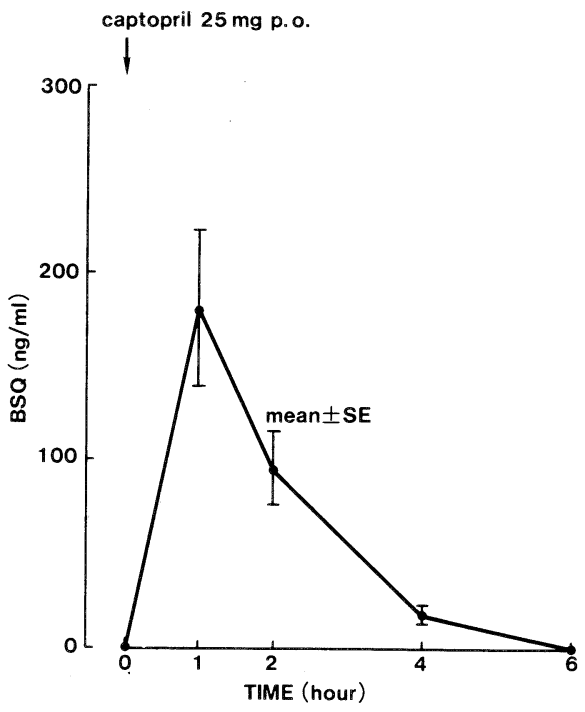

Fig. 4 Changes in blood concentration of captopril (BSQ) after the administration of captopril in patients on hemodialysis

increase during the experiment. PAC significantly decreased 1 hour after the captopril administration and decreased further. PBK significantly increased 1 hour after captopril dosing then tended to return to the base value.

Figure 3 shows the effect of captopril on ACE. ACE was significantly inhibited 1 hour after captopril and reached a nadir at two hours, then the inhibition

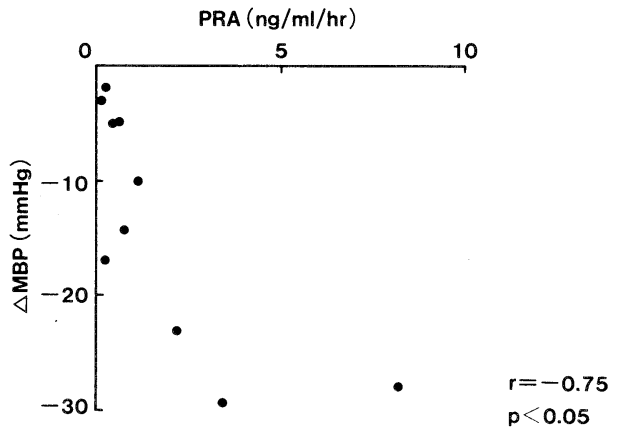

Fig. 5 Relationship between changes in mean blood pressure $(\triangle \mathrm{MBP})$ due to captopril and the basal plasma renin activity (PRA) in patients on hemodialysis

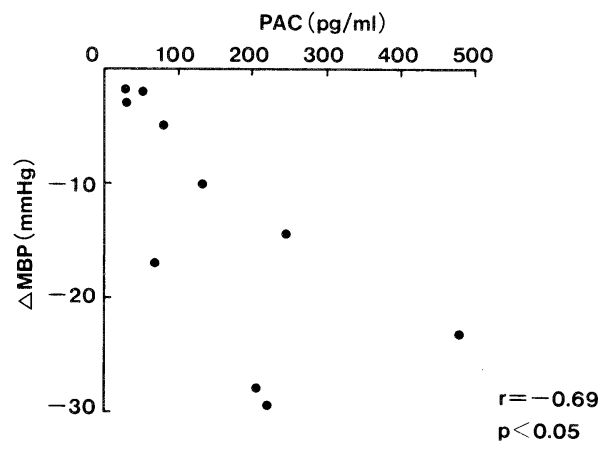

Fig. 6 Relationship between changes in mean blood pressure $(\triangle \mathrm{MBP})$ due to captopril and the basal plasma aldosterone concentration (PAC) in patients on hemodialysis

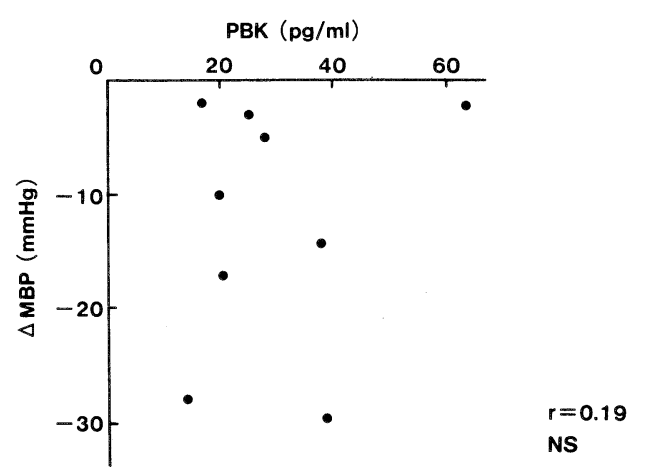

Fig. 7 Relationship between changes in mean blood pressure $(\triangle \mathrm{MBP})$ due to captopril and the basal plasma bradykinin concentration (PBK) in patients on hemodialysis 
continued for the duration of experiment.

Figure 4 shows the the changes in BSQ after captopril administration. The maximum BSQ was obtained 1 hour after the administration and it's disappearance was delayed. However, 6 hours after its administration, captopril was no longer detected in the patients' plasma.

The relationship between the changes in mean blood pressure due to captopril and basal PRA, basal PAC and basal PBK are shown in Figs. 5, 6 and 7, respectively. The changes in mean blood pressure were significantly correlated with basal PRA and basal PAC, but not with basal PBK. There was no correlation between the changes in mean blood pressure and $\mathrm{ACE}$ or BSQ.

\section{Discussion}

A number of studies have shown that the pharmacological inhibition of the renin-angiotensin system with the angiotensin-converting enzyme inhibitor captopril causes a depressor response in patients with essential hypertension, renovascular hypertension and hypertension associated with renal failure. The studies indicate that captopril lowers blood pressure mainly through its action on the renin-angiotensin system $^{1 \sim 4)}$.

In the present study, the administration of captopril significantly decreased blood pressure in patients on hemodialysis and the changes in mean blood pressure were significantly correlated with basal PRA and basal PAC. These results suggest that the mechanism of the acute antihypertensive effect of captopril in patients on hemodialysis may be mainly due to the inhibition of angiotensin II formation.

It is well known that angiotensin-converting enzyme inhibitors not only eliminate the vasoconstrictor angiotensin II but also increase the vasodilator bradykinin, because the angiotensin converting enzyme is identical to the kininase II that degradates bradykinin ${ }^{9}$. Hence, a part of the hypotensive action of captopril theoretically could be mediated by potentiation of bradykinin ${ }^{10)}$. However, captopril appears to act by interrupting angiotensin II generation, since there was no correlation in this study between the changes in mean blood pressure and basal PBK and the changes in PBK.

Pharmacokinetic data for the plasma-free form of unchanged captopril are in good agreement with the previous report ${ }^{7)}$. Also, a profound and prolonged antihypertensive response to captopril was observed in this study. However, there was no correlation between the changes in mean blood pressure and ACE or BSQ. This discrepancy between the lack of modification in captopril plasma bioavailability and the prolongation of its biological and clinical effects can not be accounted for by the action of captopril on circulating renin-angiotensin or bradykinin. Angiotensin-converting enzyme is present in the vascular endothelium ${ }^{11}$ and a physiological role for vascular renin in maintaing blood pressure has been reported ${ }^{12}$. Thus captopril may act in the blood vessel wall rather than in the circulating blood.

\section{Conclusions}

ACE was markedly suppressed and the blood pressure fell significantly 1 hour after captopril administration and these effects continued for 6 hours. PRA and PBK increased significantly and PAC was significantly reduced. The change in mean blood pressure was significantly correlated with basal PRA and basal PAC but not with basal PBK or basal ACE. Maximum BSQ was obtained 1 hour after the administration and it showed a delay in its disappearance. There was no correlation between the changes in mean blood pressure and BSQ.

These results indicate that, even in patients on hemodialysis whose blood pressure is presumably associated with volume expansion, the acute antihypertensive effect of captopril is mainly due to the inhibition of the renin-angiotensin-aldosterone ( $\mathrm{R}-\mathrm{A}$ -A) system rather than the kinin system. In conclusion, the R-A-A system may play an important role in the regulation of blood pressure in patients on hemodialysis.

\section{Acknowledgments}

We are grateful to Sankyo Pharmaceutical Co., Japan for measuring the blood concentration of captopril. The assistance of Ms. Riko Takahashi in the production of the manuscript is also acknowledged.

\section{References}

1) Gavras, H., Brunner, H. R., Turini, G. A., Kershaw, G. R., Tifft, C.P., Cuttelod, S., Gavras, I., 
Vukovich, R. A., Mckinstry, D. N. : Antihypertensive effect of the orally angiotensin converting -enzyme inhibitor SQ 14225 in man. N. Eng. J. Med., 298 : 991-995, 1978.

5) Vaughn, E. D., Carey, R. M., Ayers, C. R., Peach, M. J. : Hemodialysis-resistant hypertension : Control with an orally active inhibitor of angiotensin-converting enzyme. J. Clin. Endocrinol. Metab., 48 : 869-871, 1979.

3) Man int Veld, A. J., Schicht, I. M., Derkx, F. H. M., Bruyn, J. H. B., Schalekamp, M. A. D. H. : Effect of an angiotensin-converting enzyme inhibitor (captopril) on blood pressure in anephric subjects. Br. Med. J., 280 : 288-290, 1980.

4) Case, D. B., Allas, S. A., Laragh, J. H., Sealy, J. E., Sullivan, P. A., Mckinstry, D. N. : Clinical experience with blockade of the renin-angiotensin-aldosterone system by an oral converting-enzyme inhibitor (SQ 14225, captopril) in hypertensive patients. Progr. Cardiovasc. Dis., $21: 195-206$, 1978.

5) Swartz, S. L., Williams, G. H., Hollenberg, N. K., Moore, T.H., Dluhy, R. G. : Converting enzyme inhibition in essential hypertension: The hypotensive response does not reflect only reduced angiotensin formation. Hypertension, 1 : 106-111, 1979.

6) Johnston, C. I., Mcgrath, B. P., Millar, J. A.,
Matthews, P. G. : Long-term effect of captopril (SQ 14225) on blood pressure and hormone levels in essential hypertension. Lancet, ii : 493-495, 1979.

7) Onoyama, K., Hirakata, H., Iseki, K. : Blood concentration and urinary excretion of captopril (SQ 14,225) in patients with chronic renal failure. Hypertension, 3 : 456-459, 1981.

8) Kawahara, Y., Hisaoka, M., Yamazaki, Y., Inage, A., Morioka, T. : Determination of captopril in blood and urine by high-performance liquid chromatography. Chem. Pharm. Bull., 29: 150 $-157,1981$.

9) Erdös, E. G. : Angiotensin I converting enzyme. Cire. Res., 36 : 247-255, 1975.

10) Johnston, C. I., Clappison, B. H., Anderson, W. P., Yasujima, M. : Effect of angiotensin-converting enzyme inhibition of circulating and local kinin levels. Am. J. Cardiol., 49 : 1401-1404, 1982.

11) Ryan, J. W., Ryan, U. S., Schultz, E. : Subcellular localization of pulmonary angiotensin-converting enzyme (Kininase II). Biochem. J., $146: 497-499$, 1975.

12) Thurston, H., Swales, J.D. : Blood pressure response of nephrectomized hypertensive rats to converting enzyme inhibitor : evidence for persisting vascular renin activity. Clin. Sci. Mol. Med., 53 : 299-304, 1979. 